\title{
Development of Claw Traits and Claw Lesions in Dairy Cows Kept on Different Floor Systems
}

\author{
J. G. C. J. Somers, ${ }^{1,2}$ W. G. P. Schouten, ${ }^{1}$ K. Frankena, ${ }^{3}$ \\ E. N. Noordhuizen-Stassen, ${ }^{2}$ and J. H. M. Metz ${ }^{4}$ \\ ${ }^{1}$ Agrisystems and Environment, Agrotechnology and Food Innovations, \\ Wageningen University and Research Centrum, The Netherlands \\ ${ }^{2}$ Department of Farm Animal Health, Faculty of Veterinary Medicine, \\ Utrecht University, The Netherlands \\ ${ }^{3}$ Quantitative Veterinary Epidemiology, Department of Animal Sciences, and \\ ${ }^{4}$ Farm Technology Group, Department of Agrotechnology and Food Sciences, \\ Wageningen University, The Netherlands
}

\begin{abstract}
Several claw shape measurements, horn hardness, and horn growth and wear were recorded monthly at 12 dairy farms to investigate the effect of floor type and changes in these traits over time. Herds were either housed on a slatted floor (SL), solid concrete floor (SC), grooved floor (GR), or on a straw yard (SY). Twenty cows per farm were selected and stratified by parity. Information on claw traits was recorded on right lateral hind claws between October 2002 and May 2003. In addition, lesion development of interdigital dermatitis and heel erosion (IDHE) and digital dermatitis (DD) was studied in both rear feet. No differences in claw traits were detected among groups on different floor types, with the exception of claw angle. Claw angles were smallest in cows on SY. Claws of cows on SC were steeper than those on SL and GR. The study provided no evidence that floor-related differences in claw lesions were related to differences in horn growth, wear, and resulting claw shape. Lesions of IDHE developed gradually over time and did not differ among flooring types. Cows in SY had the smallest lesion scores for DD, whereas cows on SL had significantly less DD than cows on SC and GR. Incidence of DD fluctuated over time. Development of different stages of DD was monitored in-depth. Both early and healed stages were rather changeable and often turned into other disease stages. Classical ulcerative lesions (stage M2) persisted for a long time, with $20 \%$ of the initially unaffected claws having active lesions of DD within 5 mo. The M2 lesions generally did not cure effectively after claw trimming, and frequent use of footbaths resulted in a poor prognosis for recovery.
\end{abstract}

Received March 25, 2004.

Accepted September 22, 2004.

Corresponding author: Joan Somers; e-mail: jsomers@alpuro.nl.
(Key words: claw trait, claw lesion, floor system, digital dermatitis)

Abbreviation key: DD = digital dermatitis, GR =
grooved floor, IDHE = interdigital dermatitis and heel
erosion, $\mathbf{S C}=$ solid concrete floor, $\mathbf{S L}=$ slatted floor,
$\mathbf{S Y}=$ straw yard.

\section{INTRODUCTION}

Claw lesions and lameness are of major concern in dairy farming. A healthy locomotor apparatus is a crucial element for normal animal behavior and animal social activity. In general, claw and locomotory problems have become more serious since the introduction of loose-housing systems. Dairy producers recognize the importance of good claw care management (e.g., regular herd trimming, use of footbaths). Although improvements in housing design and nutrition have been made, incidences of claw lesions and lameness remain at a high level (Murray et al., 1996; Hedges et al., 2001). In extended studies, the number of dairy cows having claw lesions was estimated to be 70 to $80 \%$ (Manske et al., 2002; Somers et al., 2003).

It is believed that many claw lesions are the result of poor horn quality (Greenough, 1991) and overgrown claws (Russell et al., 1982; Distl et al., 1984). The bovine claw capsule is in a continuous process of turnover, and under normal conditions, horn growth and wear occur at approximately equal rates (Vermunt and Greenough, 1995). However, when cows are housed on concrete floors claw shape changes. Horn growth is accelerated by load bearing on hard surfaces (Bergsten and Stranberg, 1990; Vermunt, 1996), and the abrasiveness of concrete induces increased wear and tear (Murphy and Hannan, 1987). Prolonged upsetting of horn production together with unsatisfactory resistance of claw horn toward adverse floor conditions may result in malformation of the claw. This may threaten the locomotor apparatus, because it is generally accepted that 
strongly overgrown and malformed claws are vulnerable to mechanical injury and penetration by infectious agents.

In modern dairy farms, cows are predominantly housed in free stalls with concrete alleyways. Housing on concrete is associated with adverse claw health (Russell et al., 1982; Frankena et al., 1991; Albright, 1995), and most claw lesions occur in the lateral hind claws. Overloading of the claw is suggested to be the primary cause of claw lesions because biomechanical experiments indicated that while cows are standing on concrete, weight bearing in their hind limbs is mainly applied to the lateral claw (Toussaint-Raven, 1973; Ossent et al., 1987). Moreover, total load and pressures exerted during walking were 2-fold greater than those while standing (Scott, 1988; Van der Tol et al., 2003). A positive correlation between a prolonged stay on concrete and an increased risk for developing claw horn lesions has been established (Bergsten and Frank, 1996; Livesey et al., 1998). Mechanical stress applied to the bovine claw and limb is considerably reduced on a soft surface. In this respect, it makes sense that cows housed in straw yards have more favorable claw health than those housed in free stalls with concrete alleyways (Hughes et al., 1997; Webster, 2001; Somers et al., 2003). Moreover, it has been shown that presence and severity of claw lesions decreases on rubber floors (Hultgren and Bergsten, 2001; Benz, 2002). Abrasiveness of concrete and degree of hygiene and moisture content on the floor are also important elements in the etiology of claw disorders (Blowey and Sharp, 1988; Frankena et al., 1993; Vokey et al., 2001). For economic and management reasons, dairy cows in the Netherlands are increasingly housed in confinement during all seasons. Therefore, it is of primary importance to provide flooring surfaces that ensure healthy, normally shaped claws during unrestricted movements of the cow.

In a previous study, we showed that infectious claw disorders and hemorrhages of the sole were predominantly present in Dutch dairy cows and that their appearance was highly correlated with type of flooring (Somers et al., 2003). Some of the infectious lesions (i.e., digital dermatitis and severe heel erosion) are of major concern for animal welfare because they are long lasting, associated with pain and discomfort, and may result in lameness. Hence, risk studies were initiated to identify factors and conditions by which dairy producers may improve conditions to prevent or reduce those lesions (J. G. C. Somers, K. Frankena, E. N. NoordhuizenStassen, and J. H. M. Metz, unpublished data, 2004). But additional information on the role of flooring in the disease process is needed to develop a more radical solution to the problem. Therefore, we performed an in-depth monitoring of claw traits and development of important claw lesions (i.e., interdigital dermatitis, heel erosion, and digital dermatitis) in dairy cows housed on various flooring systems. This paper describes a longitudinal study to investigate the effect of floor design on: 1) horn growth and changes in physical characteristics of the claw, and 2) development of some important infectious claw lesions.

\section{MATERIALS AND METHODS}

\section{Study Population and Design}

The study was conducted on 12 commercial dairy farms in the Netherlands. First, farms were selected from 86 dairy herds that participated in an earlier cross-sectional survey (Somers et al., 2003). Farms with an average level of claw problems were preferentially selected. In addition, farms had to meet several selection criteria: herd size $>35$ cows, Holstein-Friesian as the breed, pasturing in the summer, and the dairy producer's willingness to collaborate on the study. Nine herds were selected, of which 3 had slatted floors (SL), 3 had solid concrete floors (SC), and another 3 had a straw yard system (SY). At the time of the study, the Dutch government mandated measures to reduce ammonia emission during renovation or development of new dairy livestock buildings. The grooved floor (GR; consisting of flat concrete floor elements with grooves at right-angles to the span of the floor elements; Swierstra et al., 1997) was one of the accredited emissionreducing floor systems. Claw health data were recorded in 10 herds kept on GR and of those, 3 herds were selected to participate in the present study.

On each farm, 20 cows were selected randomly but stratified by parity $(1,2,3$, and $\geq 4)$. We tried to include equal numbers of cows within each parity class. However, depending on the parity distribution of each herd, a greater proportion of first- and second-parity cows was selected rather than older cows. In addition, selection was based on cow lactation index (i.e., corrected rating of individual yield performance compared with the overall herd performance [set at value 100] between 80 and 110 at the latest milking record) and the expectation that the cow was not culled within the coming year. Collection of claw inspection data started at the beginning of the housing season (September or October 2002) and farms were visited at monthly intervals until May 2003. Claws of all cows were trimmed $2 \mathrm{wk}$ before the first claw inspection, which was conducted by professionals according to the Dutch trimming method (Toussaint-Raven et al., 1985). Heel horn damage was repaired and claw shape properly restored. In doing so, we assumed claws of cows to be in a comparable state at the beginning of the study. 


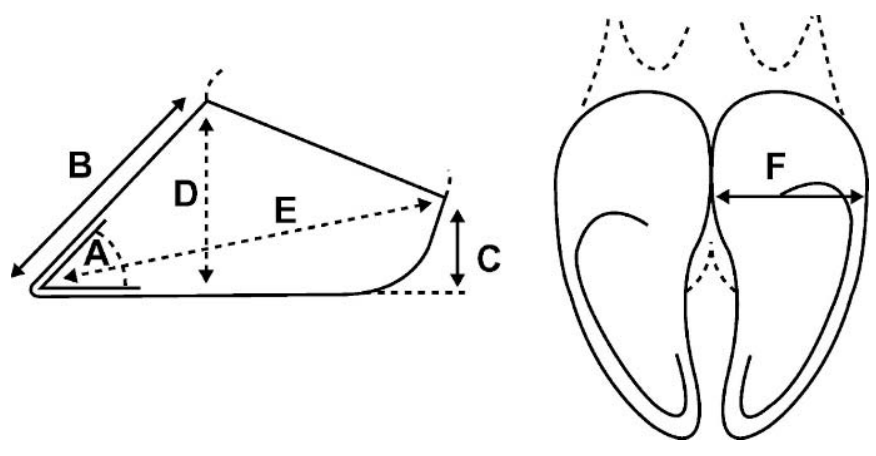

Figure 1. Illustration of various claw traits measured on the right lateral hind claws to describe claw shape (Vermunt and Greenough, 1995): $\mathrm{A}=$ claw angle; $\mathrm{B}=$ toe length; $\mathrm{C}=$ heel depth; $\mathrm{D}=$ claw height; $\mathrm{E}=$ diagonal $; \mathrm{F}=$ claw width.

\section{Claw Traits}

At each farm visit, claw shape, horn hardness, and growth and wear of the right lateral hind claw were recorded. The first author made all observations. Before inspection, the claw was brushed and caked manure was removed. Detailed measurements were performed to describe claw shape (Vermunt and Greenough, 1995; Figure 1), claw angle, toe length, heel depth, claw height, diagonal, and claw width. A cross was made at the dorsal region of the abaxial wall to measure horn growth and wear. Distances were measured between the mark and the coronal boundary and the mark and the lower edge of the claw. Changes in the distances between 2 measures were used to calculate growth and wear rates. Monthly rates of growth and wear (in $\mathrm{mm}$ per $30 \mathrm{~d}$ ) were obtained after a correction for number of days between 2 measures. Horn hardness was recorded using a Shore-A-meter (Manson and Leaver, 1988). This device measures the degree of resistance of claw horn against the penetration of a spring-loaded probe. Measurements were made in triplicate each time at 4 locations within the claw; namely the center of the heel bulb, the sole, the toe, and the outer wall. Hardness measures were averaged for each site.

\section{Claw Lesions}

Claws of both hind feet were examined for claw lesions. Interdigital dermatitis and heel erosion (IDHE) were assessed together for severity and extent on a scale of 0 to $4(0=$ heel horn intact; $1=$ slight defect of the horn integrity, pits or small fissures; $2=\vee$-shaped fissures or circular craters, extending small area of the heel; $3=\mathrm{V}$-shaped fissures or circular craters, extending entire heel; 4 = profound fissures or craters, extending to the corium of the heel). Digital dermatitis (DD) was classified to include 5 classes (M1 to M5; Döpfer, 1994) and is well suited to describe the development of DD over time: M1 = early stage with a circumscribed granulomatous area (lesion 0.5 to $2 \mathrm{~cm}$ in diameter); $\mathrm{M} 2=$ classical ulceration (lesion $>2 \mathrm{~cm}$ in diameter); $\mathrm{M} 3=$ healing lesion covered by a scab after therapy; M4 = skin alterations due to former M1 or M2 lesion; M5 = no lesion or skin abnormalities.

\section{Statistical Analyses}

Claws were trimmed at the beginning of the study and in some herds the next trimming event occurred 5 mo later. Data on claw shape, horn hardness, and IDHE are strongly influenced by claw trimming. Therefore, only recordings between 2 and 18 wk after trimming were considered eligible for analysis. Conversely, rates of horn growth and wear and DD lesions are affected less directly by trimming. Therefore, these variables recorded throughout the entire study period were used in the analysis, regardless of any subsequent trimming.

The maximum IDHE lesion score was 8 (total score of 4 for each hind foot). The DD lesion scores were coded for analysis: categories M3, M4, and M5 (healing stages or absent) were coded as 0 , whereas M1 and M2 (active lesions) were coded as 1 and 2 , respectively. The maximum lesion score for DD was 4 (M2 in both feet). A natural log (score + 0.001) transformation was applied to normalize the distribution of DD lesion scores.

Repeated data resulting from individual cows (i.e., claw traits and lesions) were subjected to a split-plot ANOVA using the GLM procedure of SAS (SAS Institute, 1996). The statistical model included the fixed effects of flooring (SL, SC, GR, or SY), time (monthly interval), and floor $\times$ time interaction, the random effect of herd nested within floor type, and the residual error. The main effect of floor type was tested by using the mean square of herd nested within floor type as the error term. All other effects were tested using the residual error as the testing term. Residuals were checked for normality using the univariate procedure in SAS and once this condition was fulfilled, the performed analysis was considered to be legitimate. When a significant effect $(P<0.10)$ for floor was detected, least square means were evaluated and $P$ values were adjusted for multiple comparisons using the Bonferroni correction. Paired $t$-tests were used to assess differences in horn growth and wear associated with claw trimming and the turnover associated with moving cows from pasture to confinement housing.

\section{RESULTS}

\section{Study Population}

Characteristics of selected herds per flooring type are summarized in Table 1. Averages of cows on the differ- 
Table 1. Average lactation number, 305-d milk yield, and herd size, and percentages of cows at various DIM on each floor type at the start of the longitudinal study.

\begin{tabular}{lrrrr}
\hline & \multicolumn{4}{c}{ Floor type $^{1}$} \\
\cline { 2 - 5 } Item & SL & SC & GR & SY \\
\hline Average lactation, no. & 2.4 & 2.4 & 2.4 & 2.5 \\
Days in milk & & & & \\
$<60$ & 21 & 17 & 30 & 19 \\
61 to 120 & 13 & 16 & 15 & 13 \\
$\geq 120$ & 66 & 67 & 55 & 68 \\
305-d milk yield, kg & 8700 & 8300 & 9000 & 8000 \\
Herd size, no. & 57 & 61 & 62 & 42 \\
\hline
\end{tabular}

${ }^{1} \mathrm{SL}=$ Slatted concrete $; \mathrm{SC}=$ solid concrete $\mathrm{GR}=$ grooved concrete; $\mathrm{SY}=$ straw yard .

${ }^{2}$ Percentage of cows in each DIM category within a floor type.

ent floor systems were comparable with regard to average lactation number and 305-d milk yield. Smaller herd sizes in SY herds are due to their labor-intensive nature and are typical for SY farms in the Netherlands (Somers et al., 2003). Cows among floor systems were evenly distributed across DIM ( $<60,60$ to $120,>120 \mathrm{~d}$ ), except for a higher proportion of early-lactation cows in GR herds.

\section{Claw Traits}

Least square means for measurements of claw shape, horn hardness, and horn growth and wear by floor type are shown in Table 2. No differences were detected in claw shape among the 4 floor types, except for claw angle $(P<0.03)$. Claw angle was by far the smallest in $\mathrm{SY}$, and claw angles for cows on SC were greater (steeper claws) than those on SL and GR. All claw shape measurements increased over time. No interaction between flooring type and time was detected, with the exception of heel depth.

Monthly changes in claw shape are shown in Table 3. Because of a floor effect $(P<0.05)$ on claw angle and an interaction $(P<0.01)$ between floor and time on heel depth, their increases over time are presented by flooring type. Claw angle on concrete floors increased 4 to $4.5^{\circ}$ within about 4 mo of trimming, whereas claws in SY became $2^{\circ}$ steeper during the same period. Toe length, claw height, and heel depth increased on average by $0.6,0.5$, and $0.6 \mathrm{~cm}$, respectively, whereas marginal changes in claw width and diagonal were observed.

Horn hardness at the toe, sole, and heel bulb was great in SY, but no main effect of floor type was detected (Table 2). Hardness at the toe, heel bulb, and wall was influenced by time $(P<0.01)$. The time-dependent change in horn hardness at each of these sites is illustrated in Figure 2.

No main effects of floor type were significant for claw horn growth, wear, and net growth (Table 2). Rates of growth and net growth changed $(P<0.01)$ over time, and interactions $(P<0.01)$ between floor type and time were detected for growth, wear, and net growth. Least square means for horn growth and wear ranged between 4.2 and $6.6 \mathrm{~mm} / \mathrm{mo}$ and 2.6 and $3.0 \mathrm{~mm} / \mathrm{mo}$, respectively (Table 4). These changes resulted in a net horn growth varying between 1.5 and $4.0 \mathrm{~mm} / \mathrm{mo}$. Both growth and net horn growth were greatest $(P<0.01)$ at the first measurement, being 1.5 to $2.5 \mathrm{~mm}$ greater

Table 2. Least square means ( \pm SEM) for claw shape measurements, horn hardness, and horn growth and wear by floor type. Data were recorded from 215 right lateral hind claws at 5 monthly measurements after claw trimming.

\begin{tabular}{|c|c|c|c|c|c|c|c|}
\hline \multirow[b]{2}{*}{ Item } & \multicolumn{4}{|c|}{ Floor type $(\mathrm{FT})^{1}$} & \multicolumn{2}{|c|}{$P$ values } & \multirow[b]{2}{*}{$\mathrm{FT} \times$ time } \\
\hline & SL & $\mathrm{SC}$ & GR & SY & FT & Time & \\
\hline Claw angle, ${ }^{\circ}$ & $46.1 \pm 0.26^{\mathrm{b}}$ & $47.8 \pm 0.29^{c}$ & $46.6 \pm 0.27^{\mathrm{b}}$ & $42.5 \pm 0.33^{\mathrm{a}}$ & 0.03 & 0.01 & NS \\
\hline Toe length, cm & $8.0 \pm 0.03$ & $7.8 \pm 0.03$ & $7.9 \pm 0.03$ & $8.0 \pm 0.04$ & NS & 0.01 & NS \\
\hline Claw width, cm & $5.7 \pm 0.02$ & $5.8 \pm 0.02$ & $5.7 \pm 0.02$ & $5.5 \pm 0.02$ & NS & 0.01 & NS \\
\hline Claw diagonal, $\mathrm{cm}$ & $13.6 \pm 0.04$ & $13.7 \pm 0.05$ & $13.8 \pm 0.04$ & $13.7 \pm 0.05$ & NS & 0.03 & NS \\
\hline Claw height, $\mathrm{cm}$ & $6.8 \pm 0.03$ & $6.7 \pm 0.03$ & $6.8 \pm 0.03$ & $6.6 \pm 0.03$ & NS & 0.01 & NS \\
\hline Heel depth, cm & $4.6 \pm 0.03$ & $4.6 \pm 0.04$ & $4.6 \pm 0.03$ & $4.3 \pm 0.04$ & NS & 0.01 & 0.01 \\
\hline Bulb & $37.8 \pm 0.35$ & $36.6 \pm 0.39$ & $36.3 \pm 0.36$ & $38.9 \pm 0.44$ & NS & 0.01 & NS \\
\hline Sole & $82.4 \pm 0.30$ & $82.6 \pm 0.34$ & $82.9 \pm 0.31$ & $84.0 \pm 0.38$ & NS & NS & 0.03 \\
\hline Toe & $89.2 \pm 0.16$ & $88.1 \pm 0.18$ & $89.9 \pm 0.17$ & $90.4 \pm 0.20$ & NS & 0.01 & 0.01 \\
\hline Wall & $92.8 \pm 0.14$ & $93.1 \pm 0.15$ & $92.6 \pm 0.14$ & $92.7 \pm 0.17$ & NS & 0.01 & 0.01 \\
\hline Growth, mm/mo & $5.3 \pm 0.13$ & $5.4 \pm 0.14$ & $4.9 \pm 0.13$ & $4.8 \pm 0.14$ & NS & 0.01 & 0.01 \\
\hline Wear, $\mathrm{mm} / \mathrm{mo}$ & $2.9 \pm 0.09$ & $2.8 \pm 0.09$ & $2.7 \pm 0.08$ & $2.3 \pm 0.09$ & NS & NS & 0.01 \\
\hline Net growth, $\mathrm{mm} / \mathrm{mo}$ & $2.4 \pm 0.14$ & $2.5 \pm 0.16$ & $2.3 \pm 0.14$ & $2.5 \pm 0.16$ & NS & 0.01 & 0.01 \\
\hline
\end{tabular}

a,b,c Means within a row having different superscript letters differ $(P<0.05)$.

${ }^{1} \mathrm{SL}=$ Slatted concrete; $\mathrm{SC}=$ solid concrete; $\mathrm{GR}$ = grooved concrete; $\mathrm{SY}=$ straw yard.

${ }^{2}$ Shore-A units range from 0 to 100 . 
Table 3. Changes in least square means for claw shape measurements for 215 right lateral hind claws after trimming. Data on claw angle and heel depth are presented by floor type because of interaction between time and floor type. ${ }^{1}$

\begin{tabular}{lrrrrr}
\hline & \multicolumn{5}{c}{ Week } \\
\cline { 2 - 6 } Item & \multicolumn{1}{c}{10} & \multicolumn{1}{c}{14} & \multicolumn{1}{c}{18} \\
\hline Claw angle, degree & & \multicolumn{1}{c}{10} & & \\
SL & $44.3 \pm 0.56$ & $45.1 \pm 0.57$ & $45.9 \pm 0.58$ & $46.8 \pm 0.59$ & $48.5 \pm 0.59$ \\
SC & $45.4 \pm 0.63$ & $46.5 \pm 0.62$ & $47.7 \pm 0.61$ & $49.4 \pm 0.60$ & $49.8 \pm 0.61$ \\
GR & $44.2 \pm 0.58$ & $46.4 \pm 0.58$ & $46.2 \pm 0.59$ & $47.6 \pm 0.61$ & $48.6 \pm 0.60$ \\
SY & $41.2 \pm 0.76$ & $42.4 \pm 0.62$ & $42.5 \pm 0.64$ & $43.0 \pm 0.69$ & $43.2 \pm 0.71$ \\
Toe length, cm & $7.6 \pm 0.03$ & $7.8 \pm 0.03$ & $8.0 \pm 0.03$ & $8.1 \pm 0.03$ & $8.2 \pm 0.04$ \\
Claw width, cm & $5.6 \pm 0.02$ & $5.6 \pm 0.02$ & $5.7 \pm 0.02$ & $5.7 \pm 0.02$ & $5.7 \pm 0.02$ \\
Claw diagonal, cm & $13.5 \pm 0.05$ & $13.7 \pm 0.05$ & $13.7 \pm 0.05$ & $13.8 \pm 0.05$ & $13.7 \pm 0.06$ \\
Claw height, cm & $6.4 \pm 0.03$ & $6.6 \pm 0.03$ & $6.7 \pm 0.03$ & $6.9 \pm 0.03$ & $6.9 \pm 0.04$ \\
Heel depth, cm & $4.3 \pm 0.07$ & $4.4 \pm 0.07$ & $4.6 \pm 0.07$ & $4.8 \pm 0.08$ & $4.9 \pm 0.08$ \\
SL & $4.2 \pm 0.08$ & $4.6 \pm 0.08$ & $4.7 \pm 0.08$ & $4.7 \pm 0.08$ & $4.6 \pm 0.08$ \\
SC & $4.1 \pm 0.07$ & $4.5 \pm 0.07$ & $4.6 \pm 0.08$ & $4.8 \pm 0.08$ & $5.0 \pm 0.08$ \\
GR & $4.0 \pm 0.10$ & $4.2 \pm 0.08$ & $4.3 \pm 0.08$ & $4.2 \pm 0.09$ & $4.5 \pm 0.09$ \\
SY & &
\end{tabular}

${ }^{1} \mathrm{SL}=$ Slatted concrete; $\mathrm{SC}=$ solid concrete; $\mathrm{GR}$ = grooved concrete; $\mathrm{SY}=$ straw yard.

than at subsequent measurements. Although all claws were trimmed before initiating the present study and cows were housed in confinement by that time, it is unclear which of those 2 factors induced accelerated horn growth. Therefore, we compared growth and wear before and after claw trimming while housed in confinement as well as horn growth after claw trimming at the changeover between pasturing and housing in confinement, and at the end of the housing season. Horn growth after claw trimming at the changeover between pasture and housing season was greater $(P<0.001)$ than after trimming at the end of the housing season (Table 5). As the difference in horn growth before and after claw trimming was insignificant, it seems clear that the increased horn growth was related to the turnover from pasture to housing. Trimming reduced $(P=$ 0.05 ) horn wear.

\section{Claw Lesions}

Interdigital dermatitis and heel erosion. Statistical analysis of IDHE categories across 5 monthly intervals after trimming revealed an effect of time $(P$ $<0.01)$. Interdigital dermatitis and heel erosion was affected neither by floor type nor by an interaction between floor type and time. Development of IDHE over time is shown in Figure 3. Trimming occurred at wk 0. At the first inspection 2 wk later, IDHE lesions were mostly absent (57\%) or mild (category 1; 37\%). By 6 and $10 \mathrm{wk}$ after trimming, the proportion of mild lesions was almost unchanged, whereas the proportion of claws with no signs of IDHE seemed to decrease to 14 and $3 \%$, respectively. About 5\% of the claws had moderate lesions (score 2) by 2 wk after trimming. From $10 \mathrm{wk}$, most IDHE lesions were of category 2 and greater. Se- verity of IDHE progressed steadily, resulting in approximately one-half of the lesions being diagnosed as serious or severe (category 3 and 4, respectively) by 18 wk and thereafter. Least square means of IDHE lesion scores seemed to increase by 3.8 points between 2 and 18 wk after trimming (Table 6 ).

Digital dermatitis. Lesions of DD tended $(P=0.07)$ to be affected by floor type. Cows in SY had the smallest DD lesion scores, whereas cows on SL had less $(P<$ 0.01) DD than cows on SC and GR. Although time did not differ in the model, a fluctuation in presence of DD lesions occurred over time within each floor system. Mean DD lesion scores had a range of 0.5 to 1.1 on SL, 1.1 to 1.6 on SC, 1.0 to 1.5 on GR, and 0.2 to 0.5 on SY (Figure 4). Variation over time was unstructured and seemed to be unrelated to duration of housing, herd trimming events (at wk 0 or from 18 wk onwards), or therapy. Most farms applied footbaths with nonantibiotic solutions such as formalin and chemical disinfectants (e.g., copper sulfate) on a biweekly or monthly basis. Despite footbath therapies, incidences of DD did not change throughout the study.

The scoring system used for DD allowed us to follow development of different disease stages. Figure 5a shows the distribution within categories M1 to M5 at 5 monthly observations. The M1 and M2 lesions ranged from 10 to $20 \%$, and 15 to $20 \%$, respectively. Healed lesions with skin abnormalities (M4) were observed in 5 to $15 \%$ of the hind claws, whereas 50 to $65 \%$ of the cases were negative (M5) with respect to DD. The M3 lesions were barely observed due to their short existence after therapy. Figures $5 \mathrm{~b}$ to $5 \mathrm{~d}$ illustrate the time course of stages M1, M2, and M5, respectively. The majority of M2 and M5 lesions remained invariable. 

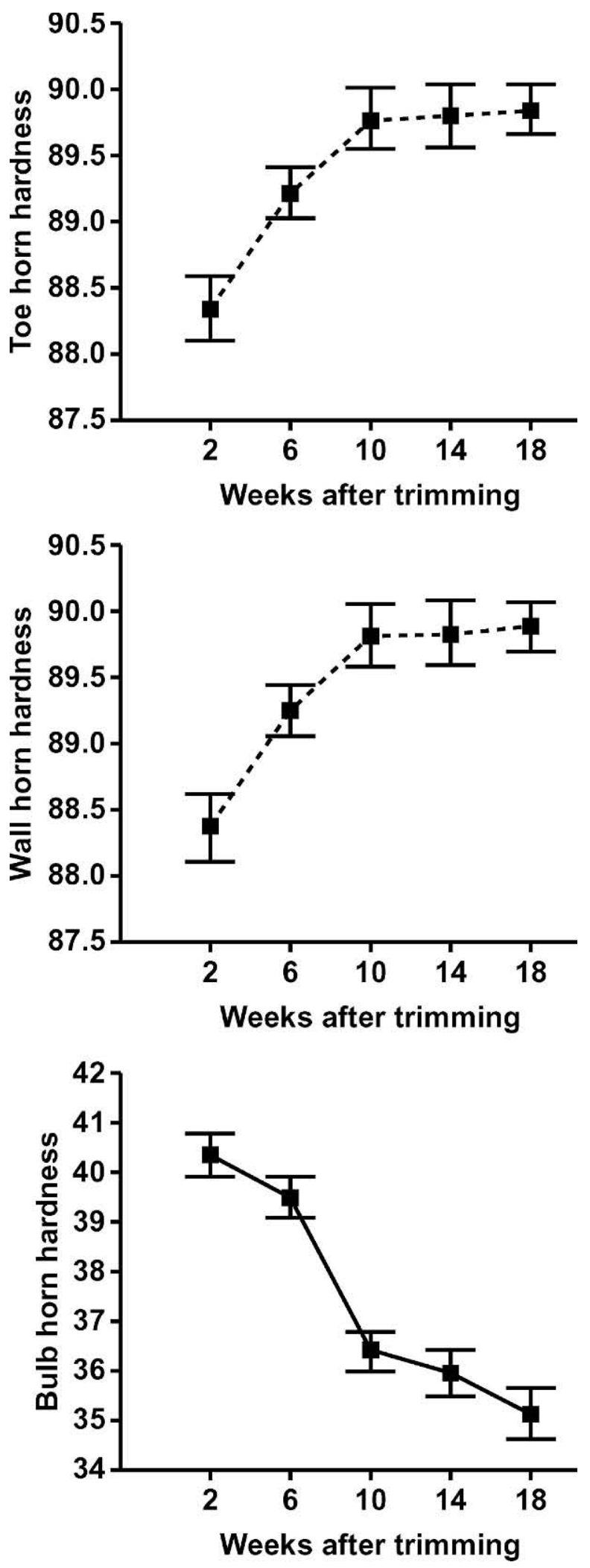

Figure 2. Changes in horn hardness of the toe, wall, and bulb of the lateral hind claws after trimming $(n=215$ dairy cows). Values are presented as means \pm SEM.
Conversely, M1 lesions were rather unstable and often turned into other disease stages.

In the present illustration of development of $\mathrm{DD}$ stages, the first observation after trimming (wk 2) was the starting point. When the second (wk 6) or third observation (wk 10) was set as the starting point, a similar picture emerged regarding M2 and M5 lesions. The M1 lesions, however, were still variable, but cured less quickly. One month after the chosen point of departure (wk 6 and 10, respectively), 70 and $68 \%$ of the M1 lesions remained as an active lesion (either as M1 or M2), whereas in Figure 5b (i.e., wk 2 as starting point) this percentage was about $40 \%$. At claw trimming, all claws generally were treated preventatively with an antibiotic spray, thus explaining the improvement of M1 lesions shortly after trimming.

\section{DISCUSSION}

It has been demonstrated that in addition to housing environment, both age and calving influence claw shape and lesion development (Alban, 1995; Vaarst et al., 1998; Offer et al., 2000; Webster, 2001). Because cows on different floor types were similar with regard to parity and stage of lactation, we assume both factors to be eliminated in the flooring comparison. Hind claws only were subjected to claw inspections because lesions are predominantly present in hind claws. For practicality, information on claw traits was obtained from right lateral hind claws only. Andersson and Lundström (1981) concluded that measurements of one hind claw are representative for estimating the size of hind claws. Although horn wear tended to be greater in lateral claws, Tranter and Morris (1992) found no difference in horn growth between the lateral and medial hind claw. Finally, Boelling and Pollott (1998) produced conclusive evidence that claw traits recorded on only one claw of one hind foot gave a representative picture of both claws on both hind feet. Significant herd effects were found for all variables observed in the present study, but were not presented. Although farm selection for each floor type included herds that were comparable with regard to housing, feeding, and management, the effect of all farm factors other than floor type are confounded with herd.

The present study investigated differences in horn growth and associated changes in claw shape in dairy cows kept on different types of flooring. It was hypothesized that concrete floors may result in malformation of claws due to disturbance in horn production and increased wear and tear (Murphy and Hannan, 1987; Vermunt and Greenough, 1995). However, we found no differences in horn growth and wear between cows on slatted (SL), flat concrete floors (SC, GR), and cows in 
Table 4. Temporal pattern of least square means for horn growth and wear rates recorded in right lateral hind claws of 215 dairy cows.

\begin{tabular}{lllllll}
\hline & \multicolumn{7}{c}{ Weeks after trimming } \\
\cline { 2 - 7 } & 2 to 5 & 6 to 9 & 10 to 13 & 14 to 17 & 18 to 21 & 22 to 25 \\
\hline Growth, $\mathrm{mm} / \mathrm{mo}$ & $6.6^{\mathrm{a}}$ & 5.0 & 5.0 & 5.1 & $4.2^{\mathrm{b}}$ & 4.8 \\
Wear, $\mathrm{mm} / \mathrm{mo}$ & 2.6 & 2.6 & 2.6 & 2.6 & 2.7 & $3.0^{\mathrm{a}}$ \\
Net growth, mm/mo & $4.0^{\mathrm{a}}$ & 2.3 & 2.4 & 2.4 & $1.5^{\mathrm{b}}$ & $1.8^{\mathrm{b}}$ \\
\hline
\end{tabular}

${ }^{\mathrm{a}, \mathrm{b}, \mathrm{c}}$ Means within week having different superscript letters differ $(P<0.05)$.

straw-based systems (SY) during a full winter season. These findings confirm those of Webster (2001), who found no effect of floor surface on horn growth and wear rates in heifers housed in free stalls or straw-based flooring. Schlichting (1987), however, reported a decreased horn growth and wear in calves kept on deep litter compared with those on concrete flooring. It was shown previously that claw lesions are less frequent and less severe in cows on straw than in free stalls (Hughes et al., 1997; Livesey et al., 1998; Webster, 2001; Somers et al., 2003). Our study, however, did not provide evidence that differences in infectious claw health among cows kept on concrete flooring and in straw are related to different horn growth and wear rates and subsequent claw shape.

Horn growth was greatest after the changeover from pasture to confinement housing. Increased growth probably was induced by a change in foot environment from soft (grassland) to hard surfaces (concrete). It is believed that increased pressures exerted to the sole- and bulb-area leads to increased horn tissue production (Murphy and Hannan, 1987). In addition, changes in feed composition when cows are moved from pasture to confinement housing may contribute to increased horn tissue growth, because it is known that it is increased in cows fed high-protein rations (Manson and Leaver, 1988). A review on wear rates varying from 3 to $7 \mathrm{~mm} /$ mo (Vermunt and Greenough, 1995) indicated that abrasion of claw horn was relatively small in our study. This may be caused by low frictional properties of the concrete alleyways. Contrary to Manson and Leaver (1989), claw trimming had no stimulating effect on horn growth. However, our observation of decreased wear after claw trimming agrees with their observations.

Free-stall housing is reported to be associated with either a decrease (Gilmore, 1978; Meyer and Galbraith, 1998) or increase in claw angle (Peterse, 1987). In the present study, claw angles on all floor types became steeper during confinement housing, with the increase occurring more rapidly in cows on concrete floors than on SY. Claw angles may become steeper by overgrowth of claw horn at the back of the claw (i.e., sole-center and bulb area as indicated by zone 4 and 6; Greenough and Vermunt, 1991), or increased horn wear underneath the toe area. Although increase in claw height and heel depth was comparable between cows on concrete and straw (Table 4), it is reasonable that cows in straw yards have less horn abrasion at the toe. Overall, claw angle was significantly smaller in cows in SY, as was observed by Meyer and Galbraith (1998). For functional weight bearing, the ideal claw angle was suggested to be at 50 to $55^{\circ}$ (Fessl, 1982). Based on normal claw shape, one could observe that weight bearing is better regulated on concrete floors. However, elasticity of concrete is nil and the hard surface exerts high contact forces to the lateral hind claw with maximum

Table 5. Analysis of effect of housing and claw trimming on horn growth and wear in dairy cows. Data are presented as mean rates per month.

\begin{tabular}{|c|c|c|c|c|c|c|}
\hline & \multicolumn{2}{|c|}{ After trimming } & \multirow{2}{*}{$\begin{array}{l}\begin{array}{l}\text { Before } \\
\text { trimming }\end{array} \\
\begin{array}{l}\text { During } \\
\text { housing }\end{array}\end{array}$} & \multirow{2}{*}{$\begin{array}{l}\text { Difference } \\
\text { between } \\
\text { groups }\end{array}$} & \multirow[b]{2}{*}{ No. } & \multirow[b]{2}{*}{$\begin{array}{l}\text { Paired } \\
t \text {-test }\end{array}$} \\
\hline & $\begin{array}{l}\text { Change- } \\
\text { over }^{1}\end{array}$ & $\begin{array}{l}\text { During } \\
\text { housing }\end{array}$ & & & & \\
\hline Growth, $\mathrm{mm} / \mathrm{mo}^{2}$ & 6.9 & 5.0 & & 1.9 & 78 & 0.001 \\
\hline Growth, $\mathrm{mm} / \mathrm{mo}^{3}$ & $\ldots$ & 5.0 & 4.8 & 0.2 & 88 & 0.484 \\
\hline Wear, $\mathrm{mm} / \mathrm{mo}$ & $\ldots$ & 2.5 & 2.9 & -0.4 & 88 & 0.025 \\
\hline
\end{tabular}

${ }^{1}$ Cows were moved from pasture to confinement housing.

${ }^{2}$ Comparison of claw horn growth in 78 animals after trimming at changeover and after trimming during confinement housing ( 6.9 vs. $5.0 \mathrm{~mm} / \mathrm{mo} ; P<0.001)$.

${ }^{3}$ Comparison of claw horn growth in 88 animals during confinement housing before trimming and after trimming ( 4.8 vs. $5.0 \mathrm{~mm} / \mathrm{mo} ; P=0.48$ ). 


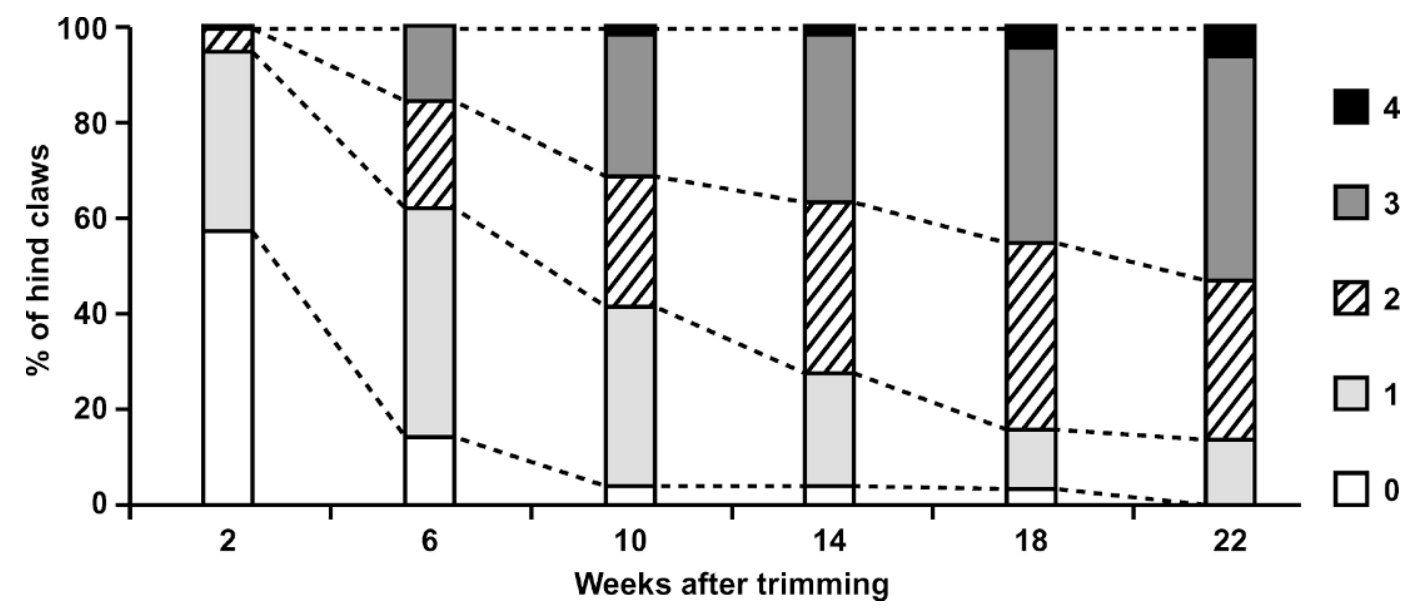

Figure 3. Distribution of the percentage of hind claws within each category of interdigital dermatitis and heel erosion (IDHE) during 5 mo after trimming (wk 0) in hind claws of 215 dairy cows. Severity and extent of IDHE was rated on a scale from 0 to $4(0=$ absent and $4=$ severe).

pressure concentrations located at the sole-bulb-area (Van der Tol, 2004). The biomechanical problem of abnormal load bearing is strongly reduced in SY because cows are less exposed to mechanical stress while standing and walking in the deep straw pack. Providing soft walking areas, e.g., rubber or straw, in general will enable a more natural weight bearing on bovine claws and this may lead to better claw health because overloading may predispose the occurrence of claw diseases (Toussaint-Raven, 1973; Bergsten and Frank, 1996; Van der Tol et al., 2003). Another way to improve functional load bearing is by claw trimming. One of the goals of the Dutch trimming method is to reduce weight bearing underneath the vulnerable part of the claw (i.e., the bulb area and sole-center; Toussaint-Raven et al., 1985). This can be achieved by increasing the claw angle that leads to a forward shift in weight bearing toward the toe. Conversely, although not presented here, we found that lateral hind claws became more shallow after trimming (on average 4 to $5^{\circ}$ ), suggesting that weight bearing on hind feet is not optimal after preventive trimming.

Claw traits other than claw angle did not differ between floor types, which is in line with previous re-

Table 6. Least square means of lesion scores for interdigital dermatitis and heel erosion (IDHE) observed in hind claws of 215 dairy cows after claw trimming. Severity and extent of IDHE was rated on a scale of 0 to $4(0=$ absent and $4=$ severe $)$. Lesion score per cow was calculated as the sum of IDHE scores in both hind feet.

\begin{tabular}{llllll}
\hline & \multicolumn{5}{c}{ Weeks after trimming } \\
\cline { 2 - 6 } & 2 & 6 & 10 & 14 & 18 \\
\hline Mean lesion score & 0.9 & 2.8 & 3.8 & 4.2 & 4.7 \\
\hline
\end{tabular}

search, in which no differences in claw dimensions were detected between cows in straw-based and free-stall housing (Fregonesi and Leaver, 2000). We expected to detect differences in horn hardness in response to flooring surface, because dirt and moisture are associated with decreased horn hardness (Baggott et al., 1988). Cows in SY are generally less exposed to foot moisture compared with cows in free-stall housing. No differences in horn hardness, however, were found between cows in SY and on concrete floors, confirming findings of Webster (2001). Conversely it was demonstrated that claws of cows on SL in Germany were harder than those on SC, whereas horn hardness was greatest on slats covered with rubber mats (Meyer, 2002).

Lesions of IDHE developed gradually over time, and disease manifestation in this study was unaffected by floor type. In contrast, in a cross-sectional survey (Somers et al., 2003), IDHE was less severe in SY than in free stalls having concrete alleyways. An explanation for the contrasting results may be the study population. The floor comparison in the cross-sectional study was based on a large sample of dairy herds, whereas in the present study, only 3 herds per floor system were studied. In addition, SY cows in the current study were comparable with the modern Dutch dairy cow with regard to milk yield and breed, whereas in the previous study, SY herds were less intensely managed. They also had (partly) other breeds than the common HolsteinFriesian (e.g., Mont-Beliarde and Jersey).

Because claws of all cows were trimmed before initiating our study, it justifies the assumption that claws exposed to different floors were comparable at the onset of the study with regard to IDHE status. An important condition for comparing claw health is the similarity 


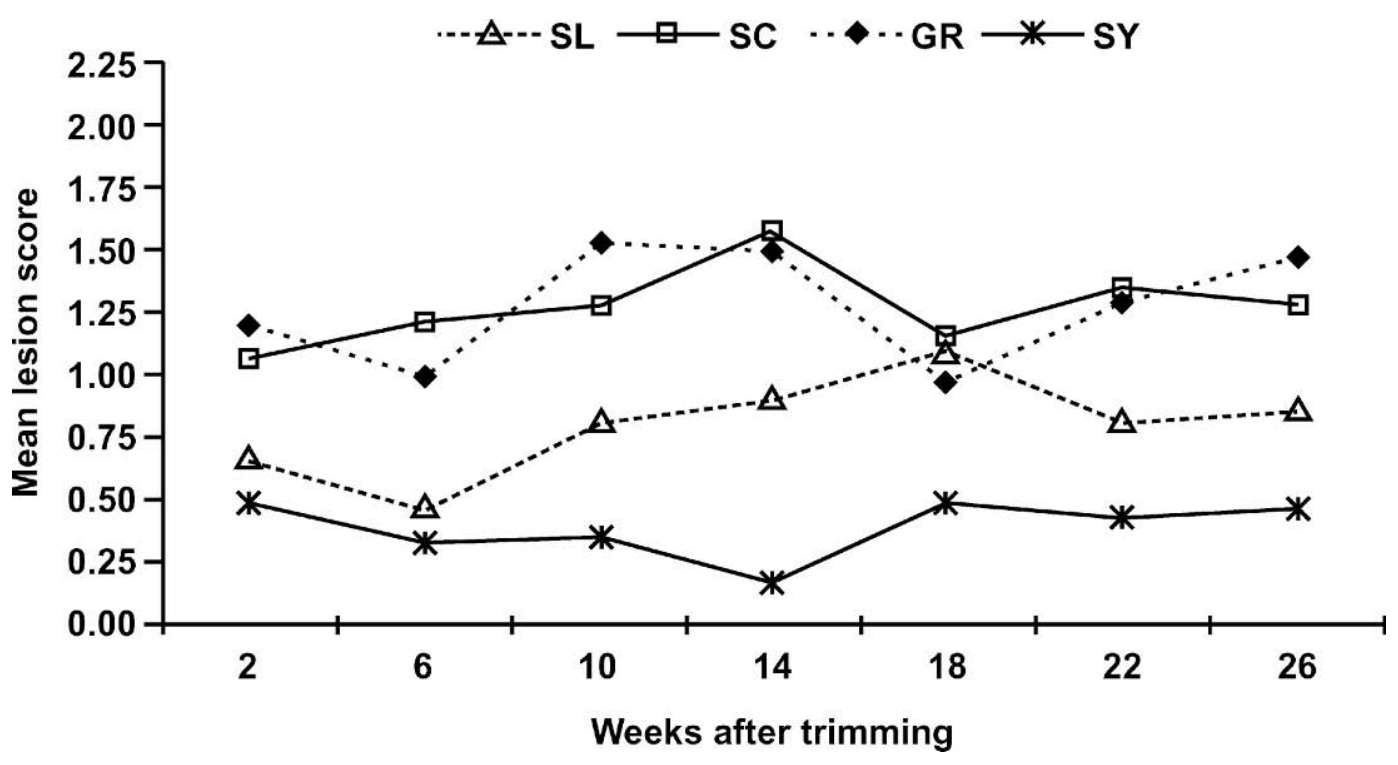

Figure 4. Mean lesion scores for digital dermatitis (DD) for 215 dairy cows kept on different floor types (SL $=$ slatted floor; SC $=$ solid concrete floor; $\mathrm{GR}=$ grooved floor; $\mathrm{SY}=$ straw yard $)$. Active DD lesions were rated on a scale from 0 to $2(0=$ absent; $1=$ moderate ulcerative lesion $<1.5 \mathrm{~cm}$ in diameter; $2=$ severe lesion $>1.5 \mathrm{~cm}$ in diameter). Lesion score per cow was calculated as the sum of the DD scores for both hind feet.

of recording intervals after trimming (Enevoldsen and Gröhn, 1991). In this respect, it is noteworthy that severe lesions of IDHE do not completely disappear after claw trimming. Although deep grooves are cut out, it takes some time before the loss of heel horn tissue is fully covered. This may be the reason that $5 \%$ of the claws in the present study already had moderate IDHE lesions $2 \mathrm{wk}$ after trimming. Nevertheless, trimming is highly advisable to restore claws from heel horn damage (Toussaint-Raven et al., 1985).

Digital dermatitis generally has been recognized as a widely occurring infectious and painful disease, often associated with lameness. Much work has been performed to clarify the etiology and provide evidence for risk factors involved (reviewed by Berry et al., 2004). The time course of DD shortly after antibiotic treatment also has been monitored (Mumba et al., 1999; Shearer and Hernandez, 2000). The present study is the first to investigate the time course of $\mathrm{DD}$ during a longer time and examine development of each of the disease stages in particular. The rate of healing in M2 lesions was about $20 \%$, whereas 30 to $60 \%$ of the M1 lesions developed into healed stages. These rates are in contrast with the $90 \%$ healing rate after antibiotic therapy reported by Brizzi (1993). After reviewing several treatment studies on DD, Shearer and Hernandez (2000) concluded that efficacy of individual treatment varies enormously, regardless of the treatment. Together with a considerable infection rate, assessed at $20 \%$ in unaffected claws during a 5-mo period, and recurrence of
M1 and M2 lesions, our results confirmed that DD is a chronic infectious disease that occurs frequently in cows exposed to current dairy housing. Given that the disease cannot be controlled without repeated antibiotic topical treatment (Bergsten, 1997), most herds in our study received nonantibiotic footbaths without significant effect. In particular, cows at stage M2 have a poor recovery prognosis from DD. Green and Döpfer (2004) credited a finely tuned host-agent equilibrium for the fact that classical ulceration (M2 lesions) persists for a long time. A dairy producer, therefore, should take extra efforts to adequately treat these problem cows, not only to save them from pain and discomfort, but also to prevent healthy animals from becoming infected. Ruling out the majority of M2 cases at a time seems a good remedy for problem herds, all the more because it is quite conceivable that the pressure of infection will structurally decrease afterwards.

\section{CONCLUSIONS}

No structural differences in claw shape were found between cows kept on several concrete flooring types and in straw yards, except for claw angle. Horn growth and wear were unaffected by floor type. Therefore, we found no evidence that differences in claw health between concrete and soft flooring are related to horn growth and wear, and associated claw shape. Lesions of IDHE increased gradually over time regardless of flooring type. Claw trimming is a good cure for the heel 
a)

$\square \mathrm{M} 5 \square \mathrm{M} 4 \square \mathrm{M} 3 \square \mathrm{M} 2 \square \mathrm{M} 1$

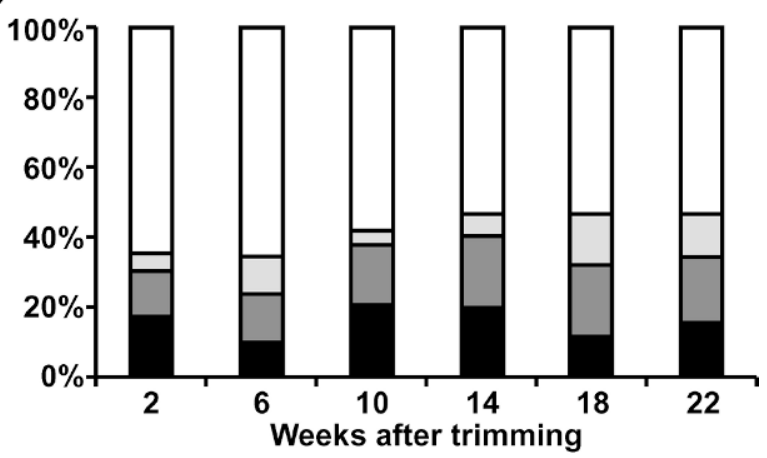

b)

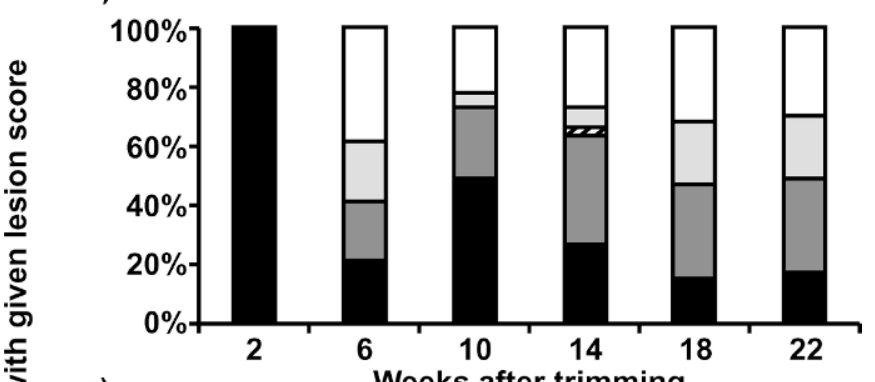

c)

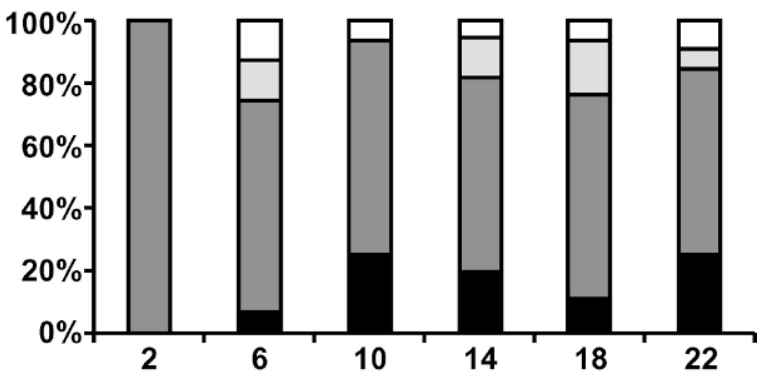

d)

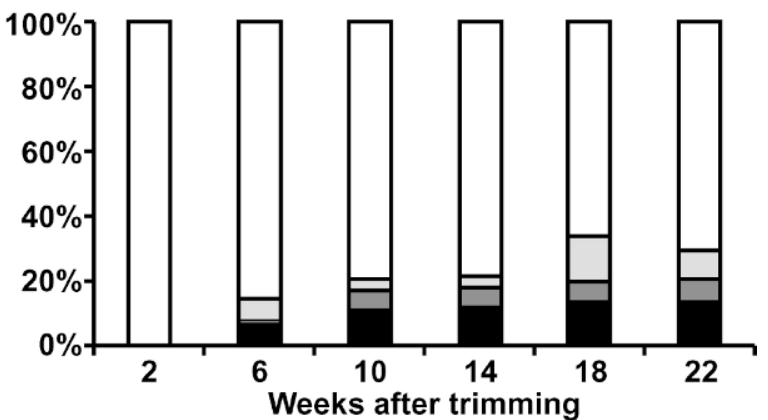

Figure 5. Changes in (a) digital dermatitis scores $[M 1=$ earlystage, granulomatous area ( 0.5 to $2 \mathrm{~cm}$ in diameter); $\mathrm{M} 2=$ classical ulcer ( 2 or more $\mathrm{cm}$ in diameter); M3 = healing process, lesion covered by scab; M4 = skin affected due to former M1 or M2 lesion; M5 = no visible lesion, skin unaffected; based on the definitions by Döpfer (1994)] and development within initial categories; (b) M1 ( $=41)$, (c) M2 (n = 32), and (d) M5 ( $=151)$ with time after housing and wk 2 as starting point. horn damage. Cows in straw yard systems were least infected by DD. Apart from this, the incidence of DD fluctuated irregularly over time. Classical lesions of DD are generally long lasting and rather insensitive to claw trimming and frequent use of footbaths.

\section{ACKNOWLEDGMENTS}

The authors gratefully acknowledge the dairy producers and their families for their cooperation and hospitality. In addition, we thank the animal science students at Wageningen University and the veterinary students at Utrecht University for their assistance in recording claw data. The Dutch Technology Foundation (STW) and the Ministry of Agriculture funded this project.

\section{REFERENCES}

Alban, L. 1995. Lameness in Danish dairy cows; frequency and possible risk factors. Prev. Vet. Med. 22:213-225.

Albright, J. C. 1995. Flooring in dairy cattle facilities. Pages 168-182 in Proc. Int. Conf. Anim. Behav. Design Livest. Poult. Systems, Indianapolis, IN.

Andersson, L., and K. Lundstrm. 1981. The influence of breed, age, bodyweight and season on digital diseases and hoof size in dairy cows. J. Vet. Med. A 28:141-151.

Baggott, D. G., K. J. Bunch, and K. R. Gill. 1988. Variations in some inorganic components and physical properties of claw keratin associated with claw disease in the British Friesian cow. Br. Vet. J. 144:534-542.

Benz, B. 2002. Elastische Beläge für Betonspaltenböden in Liegeboxenställen. Ph.D. Thesis, Univ. Hohenheim, Germany.

Bergsten, C. 1997. Infectious diseases of the digits. Pages 89-100 in Lameness in Cattle. 3rd ed. P. R. Greenough and A. D. Weaver, ed. W. B. Saunders, Philadelphia, PA.

Bergsten, C., and B. Frank. 1996. Sole haemorrhages in tied primiparous cows as an indicator of periparturient lameness: Effects of diet, flooring and season. Acta Vet. Scand. 37:383-394.

Bergsten, C., and P. Stranberg. 1990. The way to healthy hooves. Update in cattle lameness. Pages 259-261 in Proc. 6th Int. Symp. on Diseases of the Ruminant Digit, Liverpool, UK.

Berry, S. L., R. L. Walker, D. H. Read, D. W. Hird, and R. A. Ertze. 2004. The current state of knowledge on (papillomatous) digital dermatitis in dairy cattle: With particular reference to control. Pages 130-137 in Proc. 13th Int. Symp. on Lameness in Ruminants, Maribor, Slovenia.

Blowey, R. W., and M. W. Sharp. 1988. Digital dermatitis in dairy cattle. Vet. Rec. 122:505-508.

Boelling, D., and G. E. Pollott. 1998. Locomotion, lameness, hoof and leg traits in cattle I. Phenotypic influences and relationships. Livest. Prod. Sci. 54:193-203.

Brizzi, A. 1993. Bovine digital dermatitis. Bovine Pract. 27:33-37.

Distl, O., M. Huber, F. Graf, and H. Krausslich. 1984. Claw measurements of young bulls at performance testing stations in Bavaria. Livest. Prod. Sci. 11:587-598.

Döpfer, D. 1994. Epidemiological investigations about digital dermatitis on two dairy farms. Ph.D. Thesis, Tierärtzliche Hochschule, Hanover, Germany.

Enevoldsen, C., and Y. T. Gröhn. 1991. Sole ulcers in dairy cattle: Associations with season, cow characteristics, disease, and production. J. Dairy Sci. 74:1284-1298.

Fessl, L. 1982. On standardization of claw measurements in cattle. Proc. 4th Int. Symp. on Disorders of the Ruminant Digit, Paris, France.

Frankena, K., E. N. Stassen, J. P. Noordhuizen, J. O. Goelema, J. Schipper, H. Smelt, and H. Romkema. 1991. Prevalence of lame- 
ness and risk indicators for dermatitis digitalis during pasturing and housing of dairy cattle. Pages 107-118 in Proc. Ann. Symp. Soc. Vet. Epidemiol. Prev. Med., London, UK.

Frankena, K., K. A. S. van Keulen, J. P. Noordhuizen, E. N. Noordhuizen-Stassen, J. Gundelach, D. J. de Jong, and I. Saedt. 1993. A cross-sectional study of prevalence and risk factors of dermatitis interdigitalis in female dairy calves in the Netherlands. Prev. Vet. Med. 17:137-144.

Fregonesi, J. A., and J. D. Leaver. 2000. Behaviour, performance and health indicators of welfare for dairy cows housed in straw yard or cubicle systems. Livest. Prod. Sci. 68:205-216.

Gilmore, J. A. 1978. The effects of housing, age, breed and time after trimming on hoof measurements. J. Dairy Sci. 60:83.

Green, L. E., and D. Döpfer. 2004. Can epidemiology influence our understanding of lameness in cattle? Pages 33-38 in Proc. 13th Int. Symp. on Lameness in Ruminants, Maribor, Slovenia.

Greenough, P. R. 1991. A review of factors predisposing to lameness in cattle. Pages 371-393 in Breeding for Disease Resistance in Farm Animals. J. B. Owen and R. F. E. Axford, ed. CAB International, Wallingford, UK.

Greenough, P. R., and J. J. Vermunt. 1991. Evaluation of subclinical laminitis in a dairy herd and observations on associated nutritional and management factors. Vet. Rec. 128:11-17.

Hedges, V. J., R. J. Blowey, A. J. Packington, C. J. O'Callaghan, and L. E. Green. 2001. A longitudinal field trial of the effect of biotin on lameness in dairy cows. J. Dairy Sci. 84:1969-1975.

Hughes, J. W., W. B. Faull, P. J. Cripps, and N. P. French. 1997. Environmental control of bovine lameness. Cattle Pract. 5:235246.

Hultgren, J., and C. Bergsten. 2001. Effects of rubber-slatted flooring system on cleanliness and foot health in tied dairy cows. Prev. Vet. Med. 52:75-89.

Livesey, C. T., T. Harrington, A. M. Johnston, S. A. May, and J. A. Metcalf. 1998. The effect of diet and housing on the development of sole haemorrhages, white line haemorrhages and heel erosions in Holstein heifers. Anim. Sci. 67:9-16.

Manske, T., J. Hultgren, and C. Bergsten. 2002. Prevalence and interrelationships of hoof lesions and lameness in Swedish dairy cows. Prev. Vet. Med. 54:247-263.

Manson, F. J., and J. D. Leaver. 1988. The influence of dietary protein intake and of hoof trimming on lameness in dairy cattle. Anim. Prod. 47:191-199.

Manson, F. J., and J. D. Leaver. 1989. The effect of concentrate:silage ratio and hoof trimming on lameness in dairy cattle. Anim. Prod. 49:15-22.

Meyer, G. H. 2002. Modified three-area-floor with concrete elements in loose housing systems for dairy cows to improve the claw health. Pages 203-208 in Proc. Concr. Sustain. Agric., Ghent, Belgium.

Meyer, K., and H. Galbraith. 1998. Claw dimensions and rates of hoof growth and wear in Holstein dairy cows before and after turnout to pasture from concrete cubicles and straw yards. Pages 49-50 in Proc. 10th Int. Symp. on Lameness in Ruminants, Lucerne, Switzerland.

Mumba, T., D. Döpfer, C. Kruitwagen, M. Dreher, W. Gaastra, and B. A. M. van der Zeijst. 1999. Detection of spirochetes by polymerase chain reaction and its relation to the course of digital dermatitis after local antibiotic treatment in dairy cattle. J. Vet. Med. B 46:117-126.

Murphy, P. A., and J. Hannan. 1987. Effects of slatted flooring on claw shape in intensively housed fattening beef cattle. Bovine Pract. 22:133-135.
Murray, R. D., D. Y. Downham, M. J. Clarkson, W. B. Faull, J. W. Hughes, F. J. Manson, J. B. Merrit, W. B. Russell, J. E. Sutherst, and W. R. Ward. 1996. Epidemiology of lameness in dairy cattle: Description and analysis of foot lesions. Vet. Rec. 138:586-591.

Offer, J. E., D. McNulty, and D. N. Logue. 2000. Observations of lameness, hoof conformation and development of lesions in dairy cattle over four lactations. Vet. Rec. 147:105-109.

Ossent, P., D. J. Peterse, and H. C. Schamhardt. 1987. Distribution of load between the lateral and the medial hoof of the bovine hind limb. J. Vet. Med. A 34:296-300.

Peterse, D. J. 1987. Aetiology of claw disorders in dairy cattle. Pages 3-7 in Cattle Housing Systems, Lameness and Behaviour. Martinus Nijhoff Publishers, Dordrecht, The Netherlands.

Russell, A. M., G. J. Rowlands, S. R. Shaw, and A. D. Weaver. 1982. Surgery of lameness in British dairy cattle. Vet. Rec. 111:155-160.

SAS Institute. 1996. User's Guide. Statistics, Version 6.12. SAS Inst., Inc. Cary, NC.

Schlichting, M. C. 1987. Adaptation of cattle to different floor types. Pages 87-97 in Cattle Housing Systems, Lameness and Behaviour. Martinus Nijhoff Publishers, Dordrecht, The Netherlands.

Scott, G. B. 1988. Studies of the gait of Friesian heifer cattle. Vet. Rec. 123:245-248.

Shearer, J. K., and J. Hernandez. 2000. Efficacy of two modified nonantibiotic formulations (Victory) for treatment of papillomatous digital dermatitis in dairy cows. J. Dairy Sci. 83:741-745.

Somers, J. G. C. J., K. Frankena, E. N. Noordhuizen-Stassen, and J. H. M. Metz. 2003. Prevalence of claw disorders in Dutch dairy cows exposed to several floor systems. J. Dairy Sci. 86:2082-2093.

Swierstra, D., M. C. J. Smits, and C. R. Braam. 1997. Grooved concrete floor elements to reduce ammonia emission and to prevent slipperiness in a loose house for cows. Pages 263-269 in Proc. Concr. Sustain. Agric., Stavanger, Norway.

Toussaint-Raven, E. 1973. Determination of weight bearing by the cows' foot. Dutch J. Vet. Med. 5:1237-1243.

Toussaint-Raven, E., R. T. Halstra, and D. J. Peterse. 1985. Cattle Foot Care and Claw Trimming. Farming Press, Ipswich, UK.

Tranter, W. T., and R. S. Morris. 1992. Hoof growth and wear in pasture-fed dairy cattle. N.Z. Vet. J. 40:89-96.

Vaarst, M., J. Hindhede, and C. Enevoldsen. 1998. Sole disorders in conventionally managed and organic dairy herds using different housing systems. J. Dairy Res. 65:175-186.

Van der Tol, P. P. J. 2004. Biomechanical aspects of the claw-floor interaction in dairy cattle. Implications for locomotion and claw disorders. Ph.D. Thesis, Utrecht Univ., The Netherlands.

Van der Tol, P. P. J., J. H. M. Metz, E. N. Noordhuizen-Stassen, W. Back, C. R. Braam, and W. A. Weijs. 2003. The vertical ground reaction force and the distribution on the claws of dairy cows while walking on a flat substrate. J. Dairy Sci. 86:2875-2883.

Vermunt, J. J. 1996. Factors affecting the growth rate of claw horn in cattle. Page 27 in Proc. 9th Int. Symp. on Disorders of the Ruminant Digit, Jerusalem, Israel.

Vermunt, J. J., and P. R. Greenough. 1995. Structural characteristics of the bovine claw horn growth and wear, horn hardness and claw conformation. Br. Vet. J. 151:157-180.

Vokey, F. J., C. L. Guard, H. N. Erb, and D. M. Galton. 2001. Effects of alley and stall surfaces on indices of claw and leg health in dairy cattle housed in a free-stall barn. J. Dairy Sci. 84:2686-2699.

Webster, A. J. F. 2001. Effects of housing and two forage diets on the development of claw horn lesions in dairy cows at first calving and in first lactation. Vet. J. 162:56-65. 